\title{
Temporal dynamics of gastropod fauna on subtidal sandy sediments of the Ensenada de Baiona (NW Iberian Peninsula)
}

\author{
J. Moreira • C. Aldea · J. S. Troncoso
}

Received: 8 July 2009/Revised: 18 December 2009/Accepted: 22 December 2009/Published online: 6 January 2010

(C) Springer-Verlag and AWI 2010

\begin{abstract}
The temporal variation of the gastropod fauna inhabiting sandy sediments of the Ensenada de Baiona (Galicia, Spain) was studied at three subtidal sites from February 1996 to February 1997 by means of quantitative sampling. A total of 5,463 individuals representing 51 gastropod species and 22 families were found. The family Pyramidellidae was the most diverse in number of species (11 species), followed by Rissoidae and Trochidae (4 species each). The dogwhelk, Nassarius reticulatus, and the rissoid snail, Rissoa parva, were the numerically dominant species at the three studied sites; those and other abundant species showed their greatest densities by the end of summer and the beginning of autumn. In general, univariate measures of the assemblage (number of species, abundance, diversity and evenness) showed variations through time; greater values were recorded between summer and autumn depending on the site. Multivariate analyses done on abundance data showed certain seasonality in the evolution of the assemblage as expected for shallow
\end{abstract}

Communicated by Luis Gimenez.

J. Moreira $(\square)$

Estación de Bioloxía Mariña da Graña,

Universidade de Santiago de Compostela, Casa do Hórreo,

Rúa da Ribeira 1, 15590 A Graña, Ferrol, Spain

e-mail: juan.moreira@usc.es

C. Aldea - J. S. Troncoso

Departamento de Ecoloxía e Bioloxía Animal,

Facultade de Ciencias, Universidade de Vigo,

Campus de Lagoas-Marcosende s/n, 36310 Vigo, Spain

C. Aldea

Fundación Centro de Estudios del Cuaternario de

Fuego-Patagonia y Antártica (CEQUA),

Avenida Bulnes, 01890 Punta Arenas, Chile subtidal sandy sediments at temperate latitudes; those seasonal changes were mostly related to variations in abundance of numerically dominant species. Although the measured sedimentary variables did not show significant correlations with faunal univariate parameters, sediment heterogeneity due to the presence of mats of Zostera marina L. and shells of dead bivalves might explain the differences in composition of the gastropod assemblage among sampling sites.

Keywords Gastropoda - Sediment - Subtidal · Dynamics · Ensenada de Baiona - Iberian Peninsula . Atlantic Ocean

\section{Introduction}

Marine sedimentary substrata are the most common habitat in the marine environment (Snelgrove 1999) and are inhabited by a variety of benthic faunas. Distribution and composition of those faunas are conditioned by a number of abiotic factors and biotic interactions (Gray 1981). In temperate latitudes, soft-bottom benthic faunas show temporal variations in abundance of species and composition of assemblages which have been related, in turn, to seasonal changes in temperature, food supply and granulometric composition (e.g. Buchanan et al. 1974; Nichols and Thompson 1985; Dauvin and Ibanez 1986; Frid et al. 1996). The study of temporal evolution of benthic assemblages is of great interest to determine whether there are long-term changes in their structure (Josefson and Rosenberg 1988; Van Hoey et al. 2007) and to assess the scope and impact on the dynamics of benthic assemblages of the life cycles of species (Boero 1994; Constable 1999), biotic interactions (Bonsdorff and Blomqvist 1993; Turnberg and Krang 2008) 
and abiotic factors and anthropogenic disturbances (Zajac 1991; Underwood 1992; Pearson and Mannvik 1998; Hily et al. 2008). This information is paramount when formulating models and quantitative predictions about the functioning of natural systems in general, and of marine soft-bottom biota in particular (Constable 1999).

The Galician rias (NW Spain) are a kind of estuarine system defined as a stretch of coast characterized by the occurrence of a (palaeo) valley occupied by the sea (Richthofen 1886; Evans and Prego 2003). The great variety of habitats and sediments present in the rias results in diverse benthic faunas both in hard and sedimentary substrata (e.g. Mora 1982; López-Jamar et al. 1995; Olabarria et al. 1998). Their shorelines are highly populated and thus subjected to the effects of many human activities. Indeed, the soft-bottom benthic faunas of many rias are greatly affected by mussel culture, urbanization of the shoreline, paper mill discharges and urban sewage (LópezJamar et al. 1986). The effects of these perturbations mostly translate into organic enrichment and changes in sedimentary composition (López-Jamar 1978; LópezJamar and Mejuto 1985), which, in turn, results in changes in assemblages and affects the stability and dynamics of populations of many species.

Molluscs are an important component of benthic faunas in sandy marine sediments in terms of abundance and biomass (Cadée 1968; Troncoso and Urgorri 1993; Lourido et al. 2006; Laudien et al. 2007), and its study may provide valuable information about the state of benthic assemblages and environmental conditions (Bresler et al. 1999; Nehring 2005; Amin et al. 2009). Gastropods inhabiting subtidal soft bottoms have a great influence on the populations of other benthic animals; for instance, naticids and retusid opistobranchs are active predators of bivalves, and turrids prey on small polychaetes (e.g. Ansell 1960; Shimek 1983; Hiddink et al. 2002). Therefore, the study of the composition and temporal variation of gastropod assemblages may help to understand the evolution and functioning of the whole benthic assemblage. Nevertheless, specific studies on temporal dynamics of gastropod assemblages on sandy soft bottoms are scarce when compared to those devoted to other components of the benthic macrofauna (Ambrose 1991; Sardá et al. 1995; Carpentier et al. 1997; Dauvin 1998); in many occasions, those are often integrated within general studies also including bivalves, polychaetes and crustaceans.

Despite the social and economic importance of the Galician rias, there are many areas whose benthic fauna is still little known, including their gastropod faunas. This is the case of the Ensenada de Baiona, which is an inlet located south of the Ría de Vigo. Subtidal sediments are mainly sandy in most of its extension and have not been subjected to human alterations apart from some areas affected by the construction of the harbour jetty during the 1970s. Previous data on gastropods of the inlet come from taxonomic studies or checklists of species such as those provided by MacAndrew (1849), Hidalgo (1886), Rolán (1983) and Rolán et al. (1989). Recently, Moreira et al. (2009) described the spatial distribution and composition of its subtidal soft-bottom gastropod assemblages revealing the presence of a rich gastropod fauna. However, temporal dynamics of those assemblages have not been described from this area yet and have been, in general, scarcely studied in other Galician rias. In this paper, the temporal evolution of gastropod fauna on three subtidal sandy sites is described after quantitative sampling done during a 1year period; this was done to test whether there is any intraannual trend in the composition of assemblages, values of univariate measures (number of species, total abundance, diversity and evenness) and abundance of species.

\section{Materials and methods}

\section{Study area}

The Ensenada de Baiona is located on the southern margin of the mouth of the Ría de Vigo, at $42^{\circ} 07^{\prime} \mathrm{N}-42^{\circ} 09^{\prime} \mathrm{N}$ and $08^{\circ} 51^{\prime} \mathrm{W}-08^{\circ} 49^{\prime} \mathrm{W}$. The inlet is a marine environment with salinity ranging from $32 \%$ in winter to $35 \%$ in summer in the outer area and from 28 to $35 \%$ in the harbour area. The northern and eastern margins of the inlet are limited by sandy beaches; the western outer margin is exposed to the oceanic swell and winter winds (Alejo et al. 1999). Most of the inlet soft bottoms are sandy, and their distribution follows a gradient in grain size (Alejo et al. 1999; Moreira et al. 2005). Sediments at the outer mouth of the inlet are composed by very coarse to coarse sand; sedimentary substrata in the central area are dominated by medium and fine sand; sediments in the northern and eastern margins are mainly composed by fine to very fine sand fractions (Moreira et al. 2005). The harbour jetty built during the 1970s shelters the southern area around the harbour of Baiona, which has contributed to an increase of deposition of finer particles (Alejo and Vilas 1987); sediments at this area range from sandy mud to mud.

\section{Sampling}

Quantitative sampling was done at the Ensenada de Baiona in a monthly basis between February 1996 and February 1997 at three subtidal sites (Fig. 1). Sampling sites were chosen as representative of the fine-sand sediments in the inlet (Moreira et al. 2005); abiotic characteristics of the three sites are summarized in Table 1. Site D2 had scattered mats of the seagrass, Zostera marina (L.); site D15 
Fig. 1 Location of the Ensenada de Baiona and sampling sites
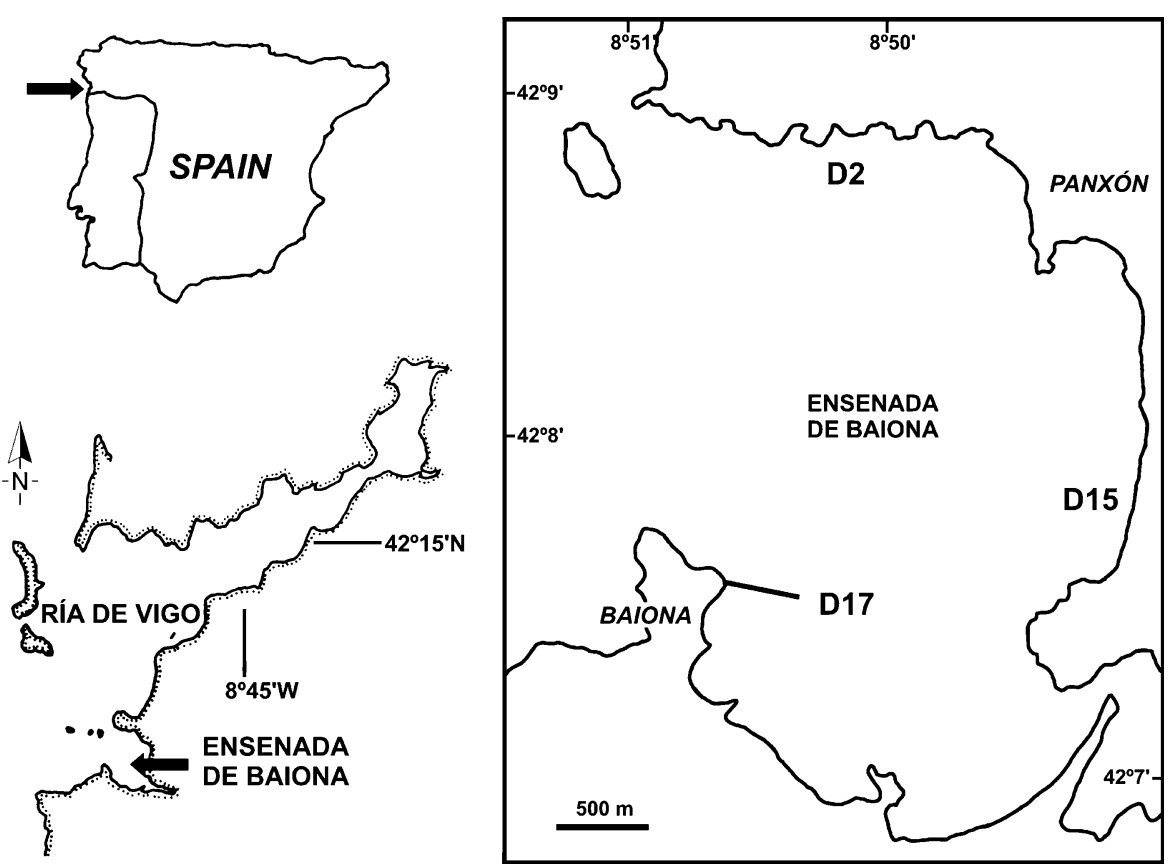

was close to the largest sandy beach in the inlet (Praia América). Sites D2 and D17 had a greater qualitative presence of shells of dead molluscs (mostly bivalves) than site D15. Five replicates were taken at each site on each date using a Van Veen grab with a sampling area of $0.056 \mathrm{~m}^{2}$, thus covering a total area of $0.28 \mathrm{~m}^{2}$. Samples were sieved through a $0.5-\mathrm{mm}$ mesh and fixed in $10 \%$ buffered formalin for later sorting and identification of the fauna. An additional sediment sample was taken at each site to determine granulometric composition, grain-size median $\left(Q_{50}\right)$, sorting coefficient $\left(S_{\mathrm{o}}\right)$ and total organic matter (TOM, \%). The following sedimentary fractions were considered: gravel $(>2 \mathrm{~mm})$, very coarse sand $(2-1 \mathrm{~mm})$, coarse sand $(1-0.5 \mathrm{~mm})$, medium sand $(0.5-0.25 \mathrm{~mm})$, fine sand $(0.25-0.125 \mathrm{~mm})$, very fine sand $(0.125-0.063 \mathrm{~mm})$ and silt/clay $(<0.063 \mathrm{~mm})$. The total organic matter content was estimated from the weight loss on combustion at $450^{\circ} \mathrm{C}$ for $4 \mathrm{~h}$ (Buchanan 1984).

\section{Data analyses}

The following univariate parameters were calculated for each date and sampling site: total abundance $(N)$, number of species $(S)$, Shannon-Wiener diversity index $\left(H^{\prime}, \log _{2}\right)$ and Pielou's evenness $\left(J^{\prime}\right)$. For each site, a one-factor ANOVA (Analysis of Variance) was used to test whether those parameters showed significant differences among sampling dates; the homogeneity of variances was previously evaluated by means of Cochran's $C$ test. Where ANOVA showed significant differences $(P<0.05)$, a post hoc Student-Newman-Keuls (SNK) test was then done for a posteriori comparisons of the means from each sampling date. Multivariate analyses were done through the PRIMER 6 software package (Clarke and Gorley 2006). A similarity matrix between samples was constructed by means of the Bray-Curtis similarity index by first applying square root transformation on species abundance to downweight the contribution of the most abundant species. Data were previously averaged through the five replicates for each date and site, thus obtaining a centroid. From the similarity matrix, a classification of the samples was done by cluster analysis based on the group-average sorting algorithm, obtaining a dendrogram. Clusters of samples determined as statistically significant by profile test SIMPROF $(P<0.05)$ were considered as having a similar gastropod composition. Non-metric multidimensional scaling (nMDS) was used to produce a visual representation of the ordination of centroids. Analyses of correlation among univariate parameters and granulometric features were done by means of the Spearman's correlation coefficient. The possible relationship between gastropod fauna and the measured sedimentary variables was explored using the BIO-ENV procedure (PRIMER). All variables expressed in percentages were previously transformed by $\log (x+1)$.

\section{Results}

Faunal composition

A total of 5,463 individuals representing 51 gastropod species belonging to 22 families were identified in samples. The family Pyramidellidae was the most diverse being 
represented by 11 species, followed by Rissoidae and Trochidae (4 species each). The gastropod fauna present at site D15 was, in general, poorer in terms of number of individuals and species than those at the other two sites (Table 1). Sites D2 and D17 showed a similar total number of individuals; site D17 was the richest in number of species. The gastropod assemblage was numerically dominated at the three sites by the dogwhelk, Nassarius reticulatus (Linnaeus, 1758), and the rissoid snail, Rissoa parva (da Costa, 1778), which both accounted for between 37 and $89 \%$ of total abundance at any given site; the calyptraeid, Calyptraea chinensis (Linnaeus, 1758), and the turritellid, Turritella communis Risso, 1826, were also abundant at site D17. At sites D2 and D17, about half of the species found were represented by less than 10 individuals in total; at site D15, all species but $N$. reticulatus, $R$. parva and the turrid, Bela nebula (Montagu, 1803), were found in small numbers (less than three individuals in total each)

For all sites, half of the species were present at least in more than $50 \%$ of samples ( 6 or more months). Ten species were shared by the three sites, of which most of them were numerically dominant ( $>1 \%$ of total dominance). Seventeen species out of the 51 found were only present in site D17, six were exclusive of site D2, and five were only found

Table 1 Geographical coordinates and summary of abiotic and biotic characteristics of the three sampling sites

\begin{tabular}{|c|c|c|c|}
\hline & \multicolumn{3}{|l|}{ Sampling site } \\
\hline & D2 & D15 & D17 \\
\hline Latitude & $42^{\circ} 08^{\prime} 50^{\prime \prime} \mathrm{N}$ & $42^{\circ} 07^{\prime} 50^{\prime \prime} \mathrm{N}$ & $42^{\circ} 07^{\prime} 30^{\prime \prime} \mathrm{N}$ \\
\hline Longitude & $08^{\circ} 50^{\prime} 15^{\prime \prime} \mathrm{W}$ & $08^{\circ} 49^{\prime} 13^{\prime \prime} \mathrm{W}$ & $08^{\circ} 50^{\prime} 15^{\prime \prime} \mathrm{W}$ \\
\hline Depth (m) & 7 & 4 & 7 \\
\hline Gravel (\%) & $6.56 \pm 8.05$ & $0.27 \pm 0.58$ & $5.41 \pm 7.94$ \\
\hline Sand $(\%)$ & $89.78 \pm 8.37$ & $94.70 \pm 2.33$ & $88.80 \pm 8.00$ \\
\hline Silt/Clay (\%) & $3.66 \pm 1.45$ & $5.03 \pm 2.51$ & $5.80 \pm 1.92$ \\
\hline $\mathrm{Q}_{50}(\mathrm{~mm})$ & $0.27 \pm 0.18$ & $0.16 \pm 0.06$ & $0.25 \pm 0.14$ \\
\hline$S_{\mathrm{o}}$ & $\begin{array}{l}\text { Poor to moderately } \\
\text { well sorted }\end{array}$ & Moderate & Bad to moderate \\
\hline TOM (\%) & $1.72 \pm 0.28$ & $2.26 \pm 0.32$ & $3.05 \pm 0.44$ \\
\hline$N$ & $64-5,982(2,499)$ & $4-254$ (334) & $46-2,725(2,630)$ \\
\hline$S$ & $6-19$ (28) & $1-7(18)$ & $6-23(40)$ \\
\hline$H^{\prime}$ & $1.06-3.26$ & $0-1.88$ & $2.20-3.59$ \\
\hline$J^{\prime}$ & $0.25-0.91$ & $0.28-0.87$ & $0.66-0.85$ \\
\hline
\end{tabular}

Values of abiotic features expressed as mean \pm standard deviation. $Q_{50}$ grain-size median, $S_{\mathrm{o}}$ sorting coefficient, $N$ number of individuals (range of monthly abundance expressed in individuals per $\mathrm{m}^{2}$, in brackets total number of specimens collected during the whole period of study), $S$ number of species (range of total monthly number of species, in brackets total number of species found in the whole period of study), $H^{\prime}$ Shannon-Wiener's diversity index (range of monthly values), $J^{\prime}$ Pielou's evenness (range of monthly values) at site D15; most of these species were collected in low numbers and were present, in general, in a few monthly samples apart from T. communis and Mangelia coarctata (Forbes, 1840) at site D17 (Table 2). Eleven species were shared by sites D2 and D17, of which C. chinensis, Gibbula cineraria (Linnaeus, 1758), G. magus (Linnaeus, 1758) and Chrysallida terebellum (Philippi, 1844) were present in at least half of the monthly samples at both sites and had a numerical dominance of between 2 and $16 \%$.

\section{Temporal dynamics}

The total number of species showed a marked variation through time at the three sites (Fig. 2a); numbers increased between the end of spring and the beginning of summer and then declined from September to October to February. At site D2, the number of individuals did not show any remarkable variation through most of the year the exception being in September, when Rissoa parva showed its greatest numerical dominance (Figs. 2b, 3b). Total abundance was low between February and June at site D17; the number of individuals increased between June and August and decreased in the following months, showing at the end of the study, similar values to those found at the beginning. Site D15 showed a similar pattern to site D17, but the total abundance was, in general, lower than in D17. Values of diversity $\left(H^{\prime}\right)$ were greater at sites D2 and D17 than at site D15 and showed great variations through the year at the three sites (Fig. 2c). The greatest values were recorded, in general, between the end of summer and the end of autumn. Evenness $\left(J^{\prime}\right)$ had greater values at site D2 and D17 than at site D15, although this was not true for July and January (Fig. 2d). At site D2, the lowest values of evenness were recorded in March, July and September, otherwise those were more or less constant and about 0.8 or greater. At site D17, evenness showed a similar pattern to that of $\mathrm{D} 2$; the lowest values were found in February and June 1996. At site D15, values of evenness were, in general, greater between summer and the beginning of autumn than in the rest of the year. At the three sites, all univariate parameters apart from evenness at site D17 showed highly significant differences between sampling dates (Table 3); SNK tests only detected significant differences among groups of samples for number of individuals at sites D2 and D17.

At site D2, most of the numerically dominant species had their greatest abundance between August and November, and mostly from September to October. On the contrary, the opisthobranch Cylichnina umbilicata (Montagu, 1803) showed peaks in abundance in spring and beginning of summer. Nassarius reticulatus was abundant all the year round (18-118 ind. $\mathrm{m}^{-2}$; Fig. 3a); Rissoa parva had a peak of abundance in September of $>5,000$ 
Table 2 Mean monthly density (individuals per $\left.\mathrm{m}^{2}\right)$, total numerical dominance $(\%)$ and presence (\%) of dominant $(>1 \%)$ and/or most frequent $(>50 \%)$ species at any of the three sampling sites

\begin{tabular}{|c|c|c|c|c|c|c|c|c|c|}
\hline \multirow[t]{3}{*}{ Species } & \multicolumn{9}{|l|}{ Sampling site } \\
\hline & \multicolumn{3}{|l|}{ D2 } & \multicolumn{3}{|l|}{ D15 } & \multicolumn{3}{|l|}{ D17 } \\
\hline & $\begin{array}{l}\text { Mean } \\
\text { abundance } \\
( \pm \mathrm{SD})\end{array}$ & $\begin{array}{l}\text { Dominance } \\
(\%)\end{array}$ & $\begin{array}{l}\text { Presence } \\
(\%)\end{array}$ & $\begin{array}{l}\text { Mean } \\
\text { abundance } \\
( \pm \mathrm{SD})\end{array}$ & $\begin{array}{l}\text { Dominance } \\
(\%)\end{array}$ & $\begin{array}{l}\text { Presence } \\
(\%)\end{array}$ & $\begin{array}{l}\text { Mean } \\
\text { abundance } \\
( \pm \text { SD })\end{array}$ & $\begin{array}{l}\text { Dominance } \\
(\%)\end{array}$ & $\begin{array}{l}\text { Presence } \\
(\%)\end{array}$ \\
\hline Gibbula cineraria & $22.0 \pm 52.5$ & 3.2 & 54 & - & - & - & $27.7 \pm 67.0$ & 3.8 & 69 \\
\hline Gibbula magus & - & - & - & - & - & - & $52.7 \pm 58.6$ & 7.3 & 92 \\
\hline Rissoa parva & $421.2 \pm 1,414.7$ & 61.3 & 85 & $11.8 \pm 16.2$ & 12.9 & 54 & $120.6 \pm 275.9$ & 16.7 & 54 \\
\hline Caecum trachea & $12.6 \pm 17.9$ & 1.8 & 85 & $0.8 \pm 2.1$ & 0.9 & 15 & $19.5 \pm 25.8$ & 2.7 & 77 \\
\hline Turritella communis & - & - & - & - & - & - & $64.3 \pm 115.8$ & 8.9 & 85 \\
\hline Calyptraea chinensis & $12.4 \pm 21.9$ & 1.8 & 69 & - & - & - & $116.8 \pm 164.2$ & 16.2 & 100 \\
\hline Euspira pulchella & $4.9 \pm 4.0$ & 0.7 & 77 & - & - & - & $6.0 \pm 4.7$ & 0.8 & 77 \\
\hline Nassarius pygmaeus & $6.9 \pm 5.9$ & 1.0 & 85 & $0.8 \pm 2.1$ & 0.9 & 15 & $19.5 \pm 24.2$ & 2.7 & 69 \\
\hline Nassarius reticulatus & $53.6 \pm 29.3$ & 7.8 & 100 & $70.1 \pm 54.6$ & 76.3 & 92 & $148.9 \pm 78.3$ & 20.6 & 100 \\
\hline Bela nebula & $9.1 \pm 7.8$ & 1.3 & 77 & $2.7 \pm 4.9$ & 3.0 & 31 & $12.9 \pm 12.1$ & 1.8 & 69 \\
\hline Mangelia coarctata & $1.1 \pm 4.0$ & 0.2 & 8 & - & - & - & $25.8 \pm 35.5$ & 3.6 & 69 \\
\hline Chrysallida terebellum & $24.5 \pm 31.3$ & 3.6 & 62 & - & - & - & $18.4 \pm 25.9$ & 2.5 & 62 \\
\hline Turbonilla pusilla & - & - & - & $0.5 \pm 1.3$ & 0.6 & 15 & $21.1 \pm 18.5$ & 2.9 & 85 \\
\hline Cylichnina umbilicata & $36.5 \pm 45.9$ & 5.3 & 77 & - & - & - & $6.9 \pm 8.2$ & 1.0 & 62 \\
\hline Retusa truncatula & $13.7 \pm 16.6$ & 2.0 & 69 & $0.3 \pm 1.0$ & 0.3 & 0.8 & $16.2 \pm 17.4$ & 2.2 & 92 \\
\hline Total dominance $(\%)$ & & 90.0 & & & 94.9 & & & 93.7 & \\
\hline
\end{tabular}

individuals per $\mathrm{m}^{2}$ (Fig. 3b). The only two species present in numbers at site D15 were $N$. reticulatus and $R$. parva; those species showed their greatest abundance in summer and autumn (Fig. 3c, d). At site D17, temporal patterns of abundance were similar to those of site D2; the dominant species showed peaks of abundance in summer and autumn (Fig. 3e, f). At this site, $R$. parva showed its greatest numbers in August; this species was better represented numerically at site D2 than at site D17. Nassarius reticulatus was present in numbers in all monthly samples; this snail was more abundant at site D17 than at the other two sites. This species showed a trend in increasing abundance from summer to autumn but also showed great fluctuations between consecutive samplings within the same season. Other species, such as Turritella communis, Gibbula cineraria, G. magus and Calyptraea chinensis, were more abundant at site D17 than at the other two; these species showed their greatest numbers in August and October.

\section{Multivariate analyses}

For site D2, SIMPROF test recognized two different groups of monthly samples from the dendrogram based on abundance data of species: one group constituted by samples from September to October and a larger group composed by all the remaining samples (Fig. 4). SIMPROF did not detect significant groups of samples for site D15, but the graphic representation of the nMDS showed a certain seasonality in the ordination of samples: those from summer-autumn were located on the left and those of winterspring on the right. Samples of site D17 were grouped into four significant clusters: two of them corresponded to samples from summer to winter and the other two from winter and spring. In general, nMDS ordinations for the three sites show that samples from the end of summer and autumn tend to be plotted together.

\section{Gastropod fauna and sedimentary features}

Analyses of correlation through the Spearman's correlation coefficient showed that, at site D15, grain-size median and coarser granulometric fractions $(>0.25 \mathrm{~mm})$ were negatively correlated with univariate parameters, but those values were not significant $(P>0.05)$. For the other two sites, correlations did not show any clear pattern and were, in general, not significant. Similarly, the BIO-ENV procedure showed low correlations among faunistic data and any combination of sedimentary features for the three sites (site D2, pw $<0.2$; site D15, pw $<0.3$ and site D17, pw < 0.4). 

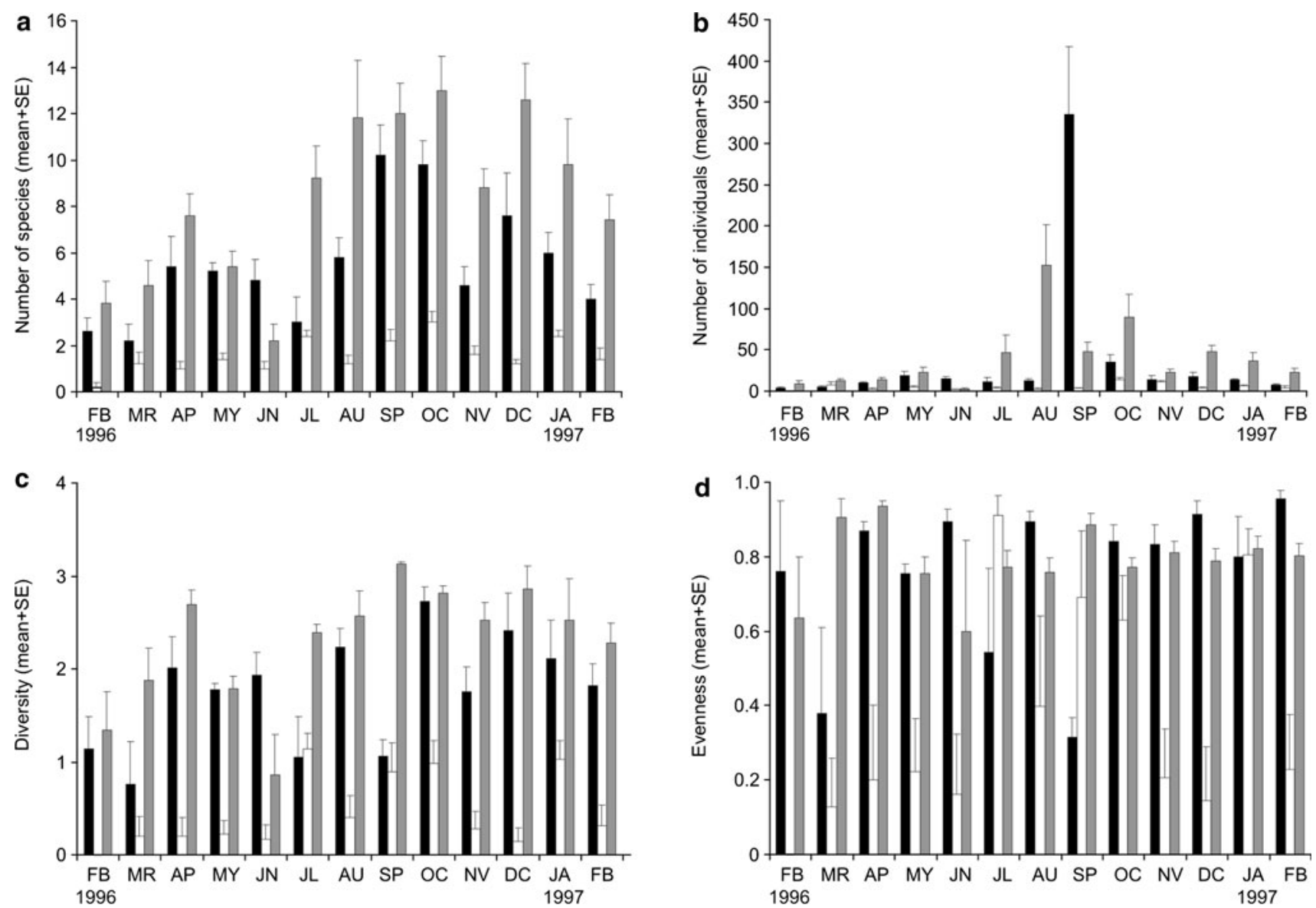

Fig. 2 Temporal variation in a number of species, b number of individuals, c Shannon-Wiener's diversity index and d Pielou's evenness (mean per replicate \pm standard error) at the three study sites

in the Ensenada de Baiona. Black bars, site D2; white bars, site D15 and grey bars, site D17

\section{Discussion}

The temporal evolution of gastropod fauna of the three studied sites showed seasonal trends similar to those reported from benthic assemblages inhabiting shallow subtidal sandy sediments at temperate latitudes (e.g. western Baltic Sea: Arntz and Rumohr 1982; North Sea: Van Hoey et al. 2007; Atlantic coast of France: Sanz 1986; southern Iberian Peninsula: Rueda et al. 2001; western Mediterranean Sea: Albertelli and Fraschetti 1995 and western North Atlantic: Holland et al. 1987). This seasonality was mostly due to variations in the number of species of the assemblage and density of the numerically dominant species through time; maximal abundances were recorded by the end of summer and the beginning of autumn. Furthermore, correlations among faunistic data and the measured sedimentary variables were weak.

In many cases, intra-annual seasonality in faunistic attributes of the assemblage (e.g. composition, abundance and diversity) is related to patterns of recruitment and

seasonal variations in food supply (Nichols and Thompson 1985; Rueda et al. 2001; Reiss and Kröncke 2005). In addition, predation and hydrodynamic stress during winter might be responsible for decrease in abundance of species (Reiss and Kröncke 2005). These facts would explain the lower values of abundance and number of species during winter and early spring in our samples; recruitment occurring during spring and an increase in food supply would lead to a posterior recovery of the assemblage. In our case, abundance and number of species were also high in early autumn as it happens in Brittany (e.g. Ibanez and Dauvin 1988); this fact has been attributed to recruitment happening not only in spring but also in summer. However, in other European areas, maximal values for these parameters are usually reported for spring and summer (Sardá et al. 1995; Rueda et al. 2001; Van Hoey et al. 2007). In the Galician rias, this situation might be related to the high primary production. In fact, upwelling events are known to occur in the rias usually twice a year, namely in spring and autumn, due to the particular hydroclimatic conditions and geographical 
Fig. 3 Temporal variation in density (individuals per $\mathrm{m}^{-2}$ ) of Nassarius reticulatus and Rissoa parva at sites D2 $(\mathbf{a}, \mathbf{b})$, D15 (c, d) and D17 (e, f)
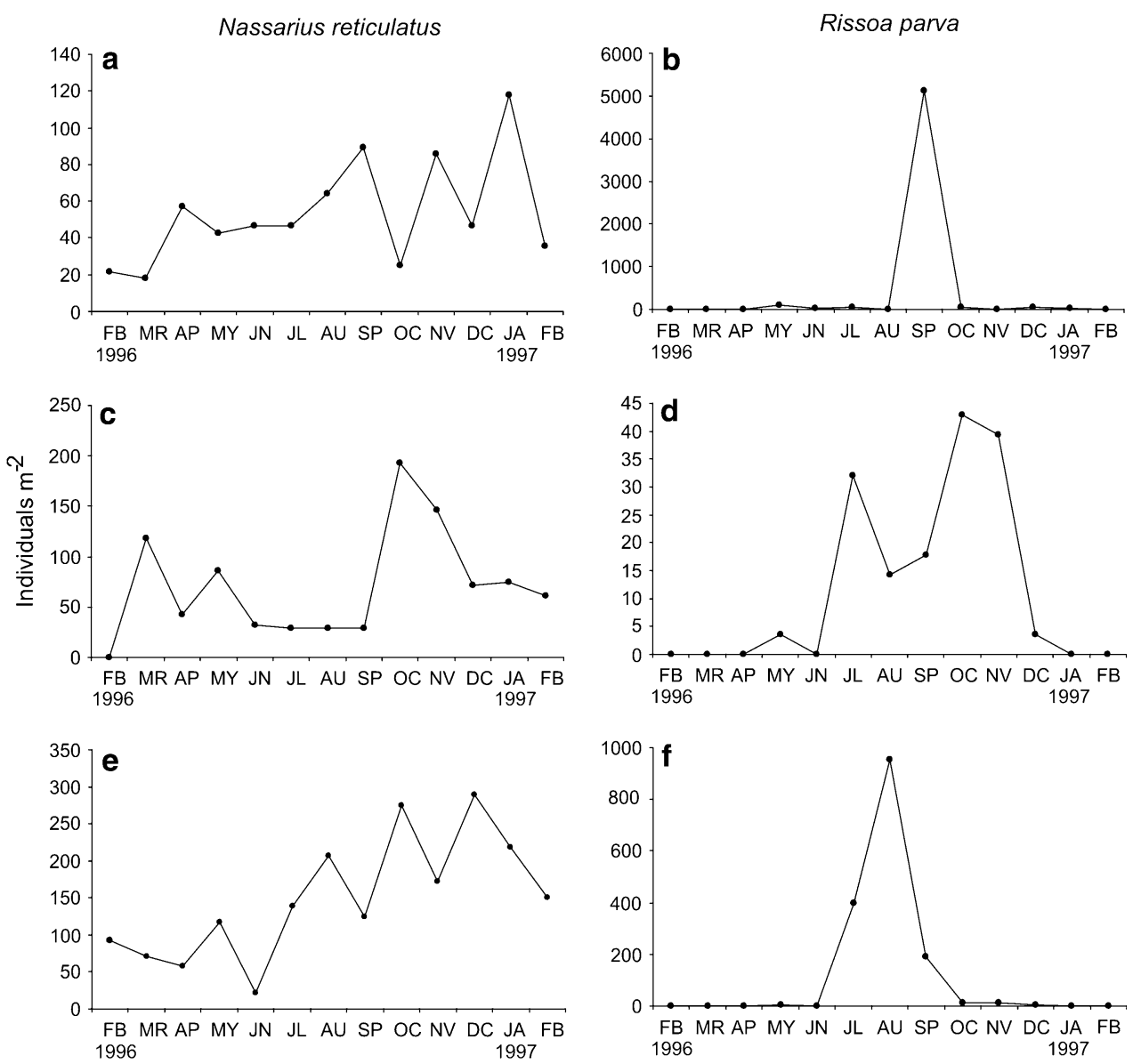

Table 3 Summary of ANOVA results for comparisons of number of species $(S)$, number of individuals $(N)$, Shannon-Wiener's diversity index $\left(H^{\prime}\right)$ and Pielou's evenness $\left(J^{\prime}\right)$ among sampling dates for each site

\begin{tabular}{llll}
\hline \multicolumn{3}{l}{ Sampling site } & \\
\cline { 2 - 4 } & $\mathrm{D} 2$ & $\mathrm{D} 15$ & $\mathrm{D} 17$ \\
\hline$S$ & $\mathrm{~F}=5.95^{* *}$ & $\mathrm{~F}=4.34^{* *}$ & $\mathrm{~F}=6.73^{* *}$ \\
$N$ & $\mathrm{~F}=15.15^{* *}$ & $\mathrm{~F}=6.39^{* *}$ & $\mathrm{~F}=5.19^{* *}$ \\
& SNK: September $>$ & & SNK: August $>$ \\
& other samples $(12)^{* *}$ & & other samples $(12)^{* *}$ \\
$H^{\prime}$ & $\mathrm{F}=3.54^{* *}$ & $\mathrm{~F}=3.90^{* *}$ & $\mathrm{~F}=5.72^{* *}$ \\
$J^{\prime}$ & $\mathrm{F}=3.39^{*}$ & $\mathrm{~F}=4.11^{* *}$ & $\mathrm{~F}=1.16 \mathrm{NS}$ \\
\hline$n=5, \quad d f=12, N S$ not significant $(P>0.05) ; * P<0.01 ; * *$ \\
$P<0.001$. Results of SNK tests are only shown when significant
\end{tabular}

features (Tenore et al. 1995; Figueiras et al. 2002). This grants a priori an important food supply until autumn which might favour to recruits from summer-autumn.

Temporal variations in abundance of some species may also be related to changes in reproductive activity and behaviour through the year. For example, some amphipods are known to migrate to deeper sediments as a reaction to changing environmental conditions (Beare and Moore
1996). In the three studied sites, the dogwhelk, Nassarius reticulatus, showed temporal fluctuations in numbers among seasons but also within seasons, mostly at sites D2 and D17 (cf. Fig. 3a, e). This species is common in coastal and estuarine habitats in Europe (Barroso et al. 2005) and shows complex behavioural responses to the environmental conditions (Tallmark 1980; Lambeck 1984); for instance, $N$. reticulatus is known to take advantage of high mortality of other benthic organisms by feeding on them (Van Hoey et al. 2007). During spring, $N$. reticulatus migrates inshore for mating, concentrating in particular areas and may return to deeper waters in autumn (Rasmussen 1973; Tallmark 1980); individuals of different sizes also segregate spatially to avoid intraspecific competition (Tallmark 1980). This behavioural plasticity might explain the aforementioned changes in abundance between consecutive sampling periods, which would overlap to seasonal changes in abundance due to recruitment and survival.

Univariate measures showed, in general, lower values at site D15 than at the other two sites; the former also had a poorer gastropod fauna in number of species. In addition, samples from winter and early spring at site D15 showed the lowest annual values for number of individuals and species. This could be explained, in part, by the greater unstability of 

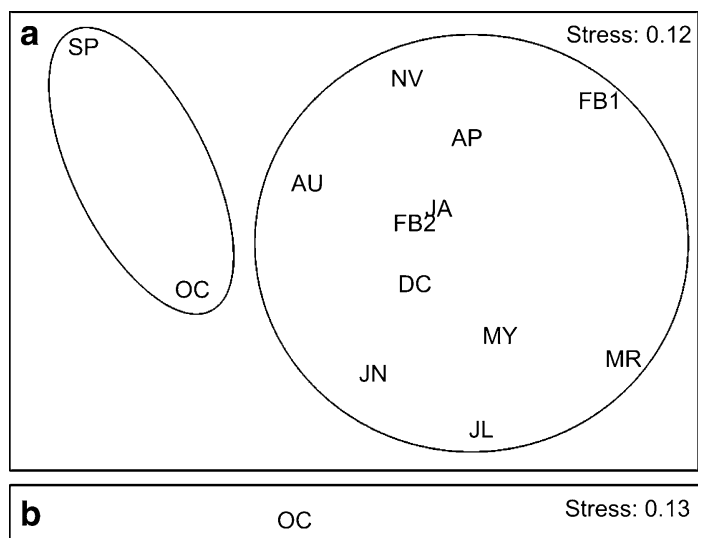

NV

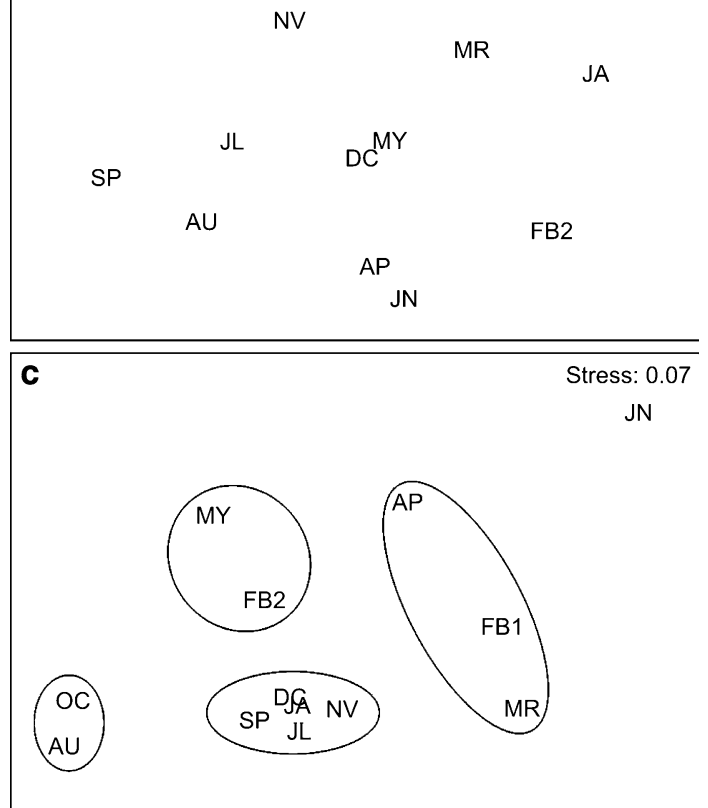

Fig. 4 nMDS ordination of monthly samples (centroids calculated on abundance data) for the three sites studied. a Site D2; b site D15; c site D17. Groups of samples determined by the SIMPROF test are shown. Sample of February 1996 for site D15 is not shown for the sake of clarity in the visualization of the ordination of the remaining samples

the sediment. In fact, this site is shallower than the other studied sites, and it is located close to the surf zone of the largest sandy beach in the inlet and therefore is subjected a priori to a greater hydrodynamism. Sediments of the surf zone are usually environments of great hydrodynamic energy (Barros et al. 2001) which translates in frequent changes in sedimentary composition and an exacerbated physical stress for the benthic fauna. In addition, hydrodynamic events associated with winter storms also affect the infauna by removing, mobilizing or burying established populations in any given area (Dobbs and Mozarik 1983; Probert 1984; Reiss and Kröncke 2005) and resuspending potential sources of food such as carrion (Chatzinikolaou and Richardson 2008); this may also lead to the disappearance of most of the macrofauna in such conditions (Carpentier et al. 1997). In fact, the grain-size median at site D15 shifted to the medium sand fraction during February 1997 when strong storms happened in the area; on the contrary, the sediment was mostly composed by the fine and very fine sand fractions for most of the year (Moreira et al. 2008). Thus, physical stress derived from hydrodynamism and disturbance of sediment would affect negatively the gastropod assemblage. Moreover, the temporal dynamics of the assemblage of peracarid crustaceans at site D15 shows a similar pattern to that of the gastropods (Moreira et al. 2008).

Although sedimentary variables did not show significant correlations with data of temporal evolution of fauna, sediment heterogeneity may explain differences in the composition of the gastropod assemblage among sampling sites (De Grave 1999; Barros 2005). Thus, the sedimentary substratum at sites D2 and D17 is more heterogenous than that at site D15, due to the presence of scattered mats of the seagrass Zostera marina at D2 and of shells of large dead bivalves at both sites (e.g. Lutraria spp. and venerids). This greater habitat heterogeneity may allow the presence of a greater number of species at those sediments than at the more homogenous and unstable sediment found at site D15. On the one hand, the presence of bioclastic components such as mollusc shells favours the presence of epifaunal species, e.g. trochids, rissoids or the calyptraeid, Calyptraea chinensis (Rueda and Salas 2003), which, otherwise, are not present on other sediments. On the other hand, sediments colonized by $Z$. marina are known to support a greater diversity of species than bare sediments, because the seagrass increases the heterogeneity of habitat, offers protection against predators and constitutes indirectly a source of food for grazers on epiphytes and microalgae (Orth 1977; Boström and Bonsdorff 1997; Arroyo et al. 2006). Thus, the greater abundance of the rissoid snail, Rissoa parva, at site D2 than at the other two sites may undoubtedly be linked to the latter fact. Moreover, numbers of this species were greater at site D2 at the end of summer before the decline of the seagrass; this pattern has also been reported for several rissoids (southern Iberian Peninsula: Arroyo et al. 2006; Rueda and Salas 2008; Rueda et al. 2008) and other epibenthic gastropod grazers (Japan: Toyohara et al. 1999; Nakaoka et al. 2001).

In conclusion, temporal evolution of the gastropod assemblages at sandy sediments of the Ensenada de Baiona shows seasonal trends that are related to both biotic and abiotic features; variations in preponderance of any given factor through the year will determine the intra-annual variability of the assemblage (Reiss and Kröncke 2005). Nevertheless, the patterns found here should be contrasted in the future with long-term data series in order to investigate inter-annual variability; this variability is known to 
happen in temperate waters due to global events rather than local (Van Hoey et al. 2007).

Acknowledgments The authors want to express their gratitude to F. J. Cristobo, C. Olabarria, P. Quintas and P. Reboreda for their help during field work, to G. Díaz-Agras for his constructive comments on an earlier version of the manuscript and to J. García-Carracedo who kindly revised the English version. We are also grateful to two anonymous referees for providing helpful comments.

\section{References}

Albertelli G, Fraschetti S (1995) A quantitative study of a macrobenthic community in the Ligurian Sea (north-western Mediterranean). Oebalia 21:103-113

Alejo I, Vilas F (1987) Dinámica litoral y evolución histórica de la Ensenada de Bayona (Pontevedra). Thalassas 5:21-32

Alejo I, Austin WEN, Francés G, Vilas F (1999) Preliminary investigations of the recent Foraminifera of Baiona Bay, N.W. Spain. J Coastal Res 15:413-427

Ambrose WG (1991) Are infaunal predators important in structuring marine soft-bottom communities? Am Zool 31:849-860

Amin B, Ismail A, Arshad A, Yap CK, Kamarudin MS (2009) Gastropod assemblages as indicators of sediment metal contamination in mangroves of Dumai, Sumatra, Indonesia. Water Air Soil Pollut 201:9-18

Ansell AD (1960) Observations on predation of Venus striatula (da Costa) by Natica alderi (Forbes). Proc Malacol Soc Lond 34:157-164

Arntz WE, Rumohr H (1982) An experimental study of macrobenthic colonization and succession, and the importance of seasonal variation in temperate latitudes. J Exp Mar Biol Ecol 64:17-45

Arroyo MC, Salas C, Rueda JL, Gofas S (2006) Temporal changes of mollusc populations from a Zostera marina bed in southern Spain (Alboran Sea), with biogeographic considerations. Mar Ecol 27:417-430

Barros F (2005) Evaluating the importance of predation on subtidal benthic assemblages in sandy habitats around rocky reefs. Acta Oecologica 27:211-223

Barros F, Borzone CA, Rosso S (2001) Macroinfauna of six beaches near Guaratuba Bay, southern Brazil. Braz Arch Biol Technol 44:351-364

Barroso CM, Moreira MH, Richardson CA (2005) Age and growth of Nassarius reticulatus in the Ria de Aveiro, north-west Portugal. J Mar Biol Assoc UK 85:151-156

Beare DJ, Moore PG (1996) The distribution, growth and reproduction of Pontocrates arenarius and P. altamarinus (Crustacea: Amphipoda) at Millport, Scotland. J Mar Biol Assoc UK 76:931-950

Boero F (1994) Fluctuations and variations in coastal marine environments. PSZN I Mar Ecol 15:3-25

Bonsdorff E, Blomqvist EM (1993) Biotic couplings on shallow water soft bottoms examples from the northern Baltic Sea. Oceanogr Mar Biol Annu Rev 31:153-176

Boström C, Bonsdorff E (1997) Community structure and spatial variation of benthic invertebrates associated with Zostera marina (L.) beds in the northern Baltic Sea. J Sea Res 37:153-166

Bresler V, Bissinger V, Abelson A, Dizer H, Sturm A, Kratke R, Fishelson L, Hansen PD (1999) Marine molluscs and fish as biomarkers of pollution stress in littoral regions of the Red Sea, Mediterranean Sea and North Sea. Helgol Mar Res 53:219-243

Buchanan JB (1984) Sediment analysis. In: Holme NA, McIntyre AD (eds) Methods for the study of marine benthos. Blackwell, Oxford, pp 41-65
Buchanan JB, Kingston PF, Sheader M (1974) Long-term population trends of the benthic macrofauna in the offshore mud of the Northumberland coast. J Mar Biol Assoc UK 54:785-795

Cadée GC (1968) Molluscan biocoenoses and thanatocoenoses in the Ria de Arosa, Galicia. Zoologische Verhandelingen 95:1-121

Carpentier P, Dewarumez JM, Leprêtre A (1997) Long-term variability of the Abra alba community in the southern bight of the North Sea. Oceanol Acta 20:283-290

Chatzinikolaou E, Richardson CA (2008) Population dynamics and growth of Nassarius reticulatus (Gastropoda: Nassariidae) in Rhosneigr (Anglesey, UK). Mar Biol 153:605-619

Clarke KR, Gorley RN (2006) PRIMER V6: user manual/tutorial. PRIMER-E Ltd, Plymouth

Constable AJ (1999) Ecology of benthic macro-invertebrates in softsediment environments: a review of progress towards quantitative models and predictions. Aust J Ecol 24:452-476

Dauvin JC (1998) The fine sand Abra alba community of the Bay of Morlaix twenty years after the Amoco Cadiz Oil Spill. Mar Pollut Bull 36:669-676

Dauvin JC, Ibanez F (1986) Long-term variations (1977-1985) of the fine sand community of Pierre Noire (Morlaix Bay, western English Channel): statistical analysis of the structural evolution. Hydrobiologia 142:171-186

De Grave S (1999) The influence of sedimentary heterogeneity on within maerl bed differences in infaunal crustacean community. Estuar Coast Shelf Sci 49:153-163

Dobbs FC, Mozarik JM (1983) Immediate effects of a storm on coastal infauna. Mar Ecol Prog Ser 11:273-279

Evans G, Prego R (2003) Rias, estuaries and incised valleys: is a ria an estuary? Mar Geol 196:171-175

Figueiras FG, Labarta U, Fernández MJ (2002) Coastal upwelling, primary production and mussel growth in the Rias Baixas of Galicia. Hydrobiologia 484:121-131

Frid CLJ, Buchanan JB, Garwood PR (1996) Variability and stability in the benthos: twenty-two years of monitoring off Northumberland. ICES J Mar Sci 53:978-980

Gray JS (1981) The ecology of marine sediments. Cambridge University Press, Cambridge

Hidalgo JG (1886) Catálogo de los moluscos recogidos en Bayona de Galicia y lista de las especies marinas que viven en la costa noroeste de España. Revista del Progreso de Ciencias Exactas, Físicas y Naturales 21:373-414

Hiddink JG, ter Hofstede R, Wolff WJ (2002) Predation of intertidal infauna on juveniles of the bivalve Macoma balthica. J Sea Res 47:141-159

Hily C, Le Loc'h F, Grall J, Glémarec M (2008) Soft bottom macrobenthic communities of North Biscay revisited: long-term evolution under fisheries-climate forcing. Estuar Coast Shelf Sci 78:413-425

Holland AF, Shaughnessy AT, Hiegel MH (1987) Long-term variation in mesohaline Chesapeake Bay macrobenthos: spatial and temporal patterns. Estuaries 10:227-245

Ibanez F, Dauvin JC (1988) Long-term changes (1977 to 1987) in a muddy fine sand Abra alba-Melinna palmata community from the Western English Channel: multivariate time-series analysis. Mar Ecol Prog Ser 49:65-81

Josefson AB, Rosenberg R (1988) Long-term soft-bottom faunal changes in three shallow fjords, West Sweden. Neth J Sea Res 22:149-159

Lambeck RHD (1984) Dynamics, migration and growth of Nassarius reticulatus (Mollusca: Prosobranchia) colonizing saline Lake Grevelingen (SW Netherlands). Neth J Sea Res 18:395-417

Laudien J, Rojo ME, Oliva ME, Arntz WE, Thatje S (2007) Sublittoral soft bottom communities and diversity of Mejillones Bay in northern Chile (Humboldt Current upwelling system). Helgol Mar Res 61:103-116 
López-Jamar E (1978) Primeros datos sobre la biomasa y la composición del bentos infaunal de la ría de Pontevedra, en relación con el contenido en materia orgánica del sedimento. Boletín del Instituto Español de Oceanografía 4:57-69

López-Jamar E, Mejuto J (1985) Bentos infaunal en la zona submareal de la ría de La Coruña. I. Estructura y distribución espacial de las comunidades. Boletín del Instituto Español de Oceanografía 2(3):99-109

López-Jamar E, González G, Mejuto J (1986) Temporal changes of community structure and biomass in two subtidal macroinfaunal assemblages in La Coruña bay, NW Spain. Hydrobiologia 142:137-150

López-Jamar E, Francesch O, Dorrío AV, Parra S (1995) Long-term variation of the infaunal benthos of La Coruña Bay (NW Spain): results from a 12-year study (1982-1993). Scientia Marina 59(Supl 1):49-61

Lourido A, Gestoso L, Troncoso JS (2006) Assemblages of the molluscan fauna in subtidal soft bottoms of the Ría de Aldán (north-western Spain). J Mar Biol Assoc UK 86:129-140

MacAndrew R (1849) On the Mollusca of Vigo Bay in the Northwest of Spain. Ann Mag Nat His 2:507-513

Mora J (1982) Consideraciones generales sobre la macrofauna bentónica de la Ría de Arosa. Oecologia aquatica 6:41-49

Moreira J, Quintas P, Troncoso JS (2005) Distribution of the molluscan fauna in subtidal soft bottoms of the Ensenada de Baiona (NW Spain). Am Malacol Bull 20:75-86

Moreira J, Gestoso L, Troncoso JS (2008) Diversity and temporal variation of peracarid fauna (Crustacea: Peracarida) in the shallow subtidal of a sandy beach: Playa América (Galicia, NW Spain). Mar Ecol 29(Suppl. 1):12-18

Moreira J, Cacabelos E, Troncoso JS (2009) Diversity and spatial distribution of the gastropod fauna (Mollusca: Gastropoda) on subtidal sedimentary substrata of the Ensenada de Baiona (Galicia, NW Iberian Peninsula). Iberus 27(1):103-117

Nakaoka M, Toyohara T, Matsumasa M (2001) Seasonal and between-substrate variation in mobile epifaunal community in a multispecific seagrass bed of Otsuchi Bay, Japan. PSZN I Mar Ecol 22:379-395

Nehring S (2005) Re-occurrence and bioindication status of the netted dog whelk Nassarius reticulatus (Linnaeus, 1758) in the Western Baltic Sea (Mecklenburg Bight, Germany). Russ J Mar Biol 31:14-20

Nichols FH, Thompson JK (1985) Time scales of change in the San Francisco Bay benthos. Hydrobiologia 129:121-138

Olabarria C, Urgorri V, Troncoso JS (1998) An analysis of the community structure of subtidal and intertidal benthic mollusks of the Inlet of Baño (Ría de Ferrol) (northwestern Spain). Am Malacol Bull 14:103-120

Orth RJ (1977) The importance of sediment stability in seagrass communities. In: Coull BC (ed) Ecology of marine benthos. University of South Carolina Press, Columbia, pp 281-300

Pearson TH, Mannvik HP (1998) Long-term changes in the diversity and faunal structure of benthic communities in the northern North Sea: natural variability or induced instability? Hydrobiologia 375(376):317-329

Probert PK (1984) Disturbance, sediment stability, and trophic structure of soft-bottom communities. J Mar Res 42:893-921

Rasmussen E (1973) Systematics and ecology of the Iselfjord marine fauna (Denmark). Ophelia 11:1-507

Reiss H, Kröncke I (2005) Seasonal variability of infaunal community structures in three areas of the North Sea under different environmental conditions. Estuar Coast Shelf Sci 65:253-274
Richthofen FV (1886) Führer für Forschungsreisende. Oppenheim, Berlin

Rolán E (1983) Moluscos de la Ría de Vigo I. Gasterópodos. Thalassas 1, annexe 1:1-383

Rolán E, Otero J, Rolán-Álvarez E (1989) Moluscos de la Ría de Vigo II. Thalassas 7, annexe 2:1-276

Rueda JL, Salas C (2003) Temporal dynamics of molluscan assemblages from soft and bioclastic bottoms in the Strait of Gibraltar. Cahiers de Biologie Marine 44:237-248

Rueda JL, Salas C (2008) Molluscs associated with a subtidal Zostera marina L. bed in southern Spain: linking seasonal changes of fauna and environmental variables. Estuar Coast Shelf Sci 79:157-167

Rueda JL, Fernández-Casado M, Salas C, Gofas S (2001) Seasonality in a taxocoenosis of molluscs from soft bottoms in the Bay of Cádiz (southern Spain). J Mar Biol Assoc UK 81:903-912

Rueda JL, Urra J, Salas C (2008) Diel and seasonal variation of a molluscan taxocoenosis associated with a Zostera marina bed in southern Spain (Alboran Sea). Helgol Mar Res 62:227-240

Sanz A (1986) Évolution des paramètres de structure des peuplements annélidiens des fonds infralittoraux situés au large du Bassin d'Arcachon. Cahiers de Biologie Marine 27:133-152

Sardá R, Martín D, Pinedo S, Dueso A, Cardell MJ (1995) Seasonal dynamics of shallow soft-bottom communities in western Mediterranean. In: Eleftheriou A et al (eds) Biology and ecology of shallow coastal waters. Olsen \& Olsen, Fredensborg, pp 191198

Shimek RL (1983) The biology of the northeastern Pacific Turridae II. Oenopota. J Molluscan Stud 49:146-163

Snelgrove P (1999) Getting to the bottom of marine biodiversity: sedimentary habitats-ocean bottoms are the most widespread habitat on Earth and support high biodiversity and key ecosystem services. Bioscience 49:129-138

Tallmark B (1980) Population dynamics of Nassarius reticulatus (Gastropoda, Prosobranchia) in Gullmar Fjord, Sweden. Mar Ecol Prog Ser 3:51-62

Tenore KR, Alonso-Noval M, Álvarez-Ossorio M, Atkinson LP, Cabanas JM, Cal RM, Campos HJ, Castillejo F, Chesney EJ, González N, Hanson RB, McClain CR, Miranda A, Román MR, Sánchez J (1995) Fisheries and oceanography off Galicia, NW Spain: mesoscale spatial and temporal changes in physical processes and resultant patterns of biological productivity. J Geophys Res 100:10943-10966

Toyohara T, Nakaoka M, Aioi K (1999) Population dynamics and reproductive traits of phytal gastropods in seagrass bed in Otsuchi Bay, north-eastern Japan. PSZN I Mar Ecol 19:162-178

Troncoso JS, Urgorri V (1993) Datos sedimentológicos y macrofauna de los fondos infralitorales de sustrato blando de la Ría de Ares y Betanzos. Nova Acta Científica Compostelana (Bioloxía) 4:153166

Turnberg BG, Krang D (2008) Composition and temporal change of the macrofauna in a shallow, snady bottom in the Lysekil archipelago, western Sweden. Mar Biol Res 4:458-469

Underwood AJ (1992) Beyond BACI: the detection of environmental impacts on populations in the real, but variable world. J Exp Mar Biol Ecol 161:145-178

Van Hoey G, Vincx M, Degraer S (2007) Temporal variability in the Abra alba community determined by global and local events. J Sea Res 58:144-155

Zajac RN (1991) Demographic aspects of marine, soft sediment patch dynamics. Am Zool 31:808-820 